\title{
FROM RECORD CONTRACT TO ARTREPRENEUR? \\ Musicians' Self-Management and the Changing Illusio in the Music Market
}

\author{
Holger Schwetter \\ DHGS, Hochschule für Sport \& Kunst \\ (University of Applied Sciences for Health \& Sport) \\ holger@schwetter.de
}

\begin{abstract}
This article contrasts present conceptions of pop musicians' career development with ideas from the 1960s to 1990s. It identifies two divergent key concepts: the artrepreneur and the record contract. As a counterpart, the article evaluates empirical findings from an interview study with German and US-American musicians to answer the following research question: How are concepts of career management advocated and how are they related to the musician's practices? This research suggests that in the 1970s to 1990s, self-management was regarded as a necessary evil before getting a recording contract, which was seen as a central aim for musicians. This widespread concept stood in stark contrast to the actual conditions of work in the field and can thus be described as forming an important part of the illusio (in Bourdieu's sense), motivating participation while at the same time masking the actual working conditions. Today, in the age of digital communication networks, the record contract is no longer as crucial as it used to be. Instead, self-management is presented as a new, central, and legitimate strategy to push musicians' careers forward even though studies show that the chances for independent musicians have not grown. The concept of the musician as artrepreneur replaced the hopes that were connected with the record contract. This shift is part of a new illusio that now motivates the musician's participation in the music market. This paper attempts a small contribution toward unmasking the illusions that are connected with the illusio, which for Bourdieu is among the central functions of sociology.
\end{abstract}

\section{Keywords}

digital music market; internet platforms; musicians; music distribution; record labels 


\begin{abstract}
About the Author
Holger Schwetter studied Musicology and Media Science at the University of Osnabrueck, Germany. He has a long-term experience in media, music, and culture production. He carried out his doctoral research with a grant by the Hans-Boeckler-Foundation within the PhD program "productivity of culture," conducting a study on digital self-management and the use of copyright by musicians in Germany and the USA. The resulting book, "Teilen - und dann? Kostenlose Musikdistribution, Selbstmanagement und Urheberrecht” ("Sharing - What Else? Free Music Distribution, Self-management and Copyright"), was published in 2015. He was a researcher at the Institute of Sociology at the Technical University Dresden from 2014 to 2017. In the research project "Time has come today," he worked on experiences with popular music in the west German countryside and their connection to social change in the 1970s and 1980s. Currently, he is a lecturer at the DHGS, University of Applied Sciences for Health \& Sport in Berlin, Germany for the bachelor course on music production.
\end{abstract}




\section{INTRODUCTION}

It cannot be doubted that the conditions for music distribution have altered fundamentally with the establishment of digital communications networks, first and foremost the internet. This has been described and discussed from different perspectives, such as record labels and their business models, music distribution by internet users, the legal and cultural implications of digital copying and remixing. ${ }^{1}$ Many activities that were shared among a small circle of friends, such as recommending and copying music or playing cover versions of popular songs became internationally interconnected with the advent of the internet and new software platforms like Napster or YouTube. In this way, former private activities became public and thus subject to copyright law as well as to new (music) business models. In contrast to old ideas of the consumer as being somewhat passive and just "using" the products the music industry offers him, it has become obvious that the consumer-now an internet user-is pursuing all kinds of activities.

Musicians were affected in a similar fashion. As internet users, they can make low budget, homemade productions visible to the public. One of the first successful social media platforms was MySpace. It offered special services for musicians: They could upload songs, write stories, and connect and interact directly with their fans. For the first time in the history of the music market, it was possible to potentially reach an international audience with the means of direct marketing. Musicians did not need a record company or other intermediaries to engage with their fans and promote their music online. The power of self-management seemed to be intensified, and traditional intermediaries like record companies apparently lost ground (Huber).

In order to understand the changes described above from a theoretical perspective, it is popular to express the perceived changes in consumer roles in composite phrases, combining what seemed incompatible in the past and turning to the future in an occasionally almost prophetic fashion. Some of the most striking terms are "prosumer," a combination of "consumer" and "producer" (Abresch), and "pro-am," comprising of the "professional" and the "amateur" (Leadbeater and Miller). The term "artrepreneur" was coined to describe musicians, indicating a new role that combines artist and entrepreneur in one (Smudits). This frequent use of portmanteau words suggests that the established categories no longer seem fitting in the face of new experiences. The diversity of terminology can certainly be regarded as an indication of social changes. However, to determine the nature and extent of possible transformation indexed in this way, it is helpful to examine the current changes empirically and to compare the findings with the situation in the recent past, before the developments that are now described as a radical break. This article therefore approaches the concept of the artrepreneur from a combined 
historical and empirical perspective. It aims to contextualize the current debates on role models for musicians with respect to their function within the dynamics of the music market's overall development. It does so in order to challenge widespread assumptions that digitization leads to the democratization of the music market and better career chances for musicians.

The musicians' self-management as an entrepreneurial activity is the pivotal point for this investigation. The guiding question is "how are concepts of career management advanced and related to the musicians' practices?" Management is defined here as including all aspects of musicians' economic organization and marketing: the conception and implementation of self-presentation in public, the production, organization and distribution of music, the acquisition of concerts and accounting, and much more. Self-management means that a musician ${ }^{2}$ is responsible for most of these tasks herself. With this focus, a specific question arises: How can we comprehend the relation between artistic and management activities for independent musicians before and after the advent of the internet? Generally speaking, the combination of such skills or activities by musicians is not a new phenomenon; on the contrary, it permeates the history of Western music as a possible form of economic livelihood for musicians since the Middle Ages, at the latest, as Herzberg shows (37). ${ }^{3}$ The transition to digital production, marketing, and distribution known as the digital mediamorphosis (Smudits) functions as a hinge in this context, a shift from which comparative investigations regarding self-management can be undertaken-a comparison, that is, of the period directly before the digital mediamorphosis and then afterwards, which includes a consideration of the theoretical conceptions on the one hand and their practice on the other. The relations between theory and practice are particularly interesting as the prominence of certain concepts might serve certain functions in the field of popular music production. ${ }^{4}$ In ethnography, an awareness is growing recently concerning the constant cognitive exchange between the field and research (Hegner). A similar connection is relevant in culture and media markets, and this article aims to investigate certain manifestations of this relation.

The concept of the artrepreneur serves as reference point because, first of all, it represents a prominent aspect in a discourse focusing on the question of how markets and society are being modified by the effects of digitization. As the music market was exposed to such effects very early on, it plays a crucial part in these discourses. In addition, the concept carries a very specific understanding of self-management. The narrative that follows begins with a presentation of some conceptual definitions of the artrepreneur in order to decipher this understanding. I then explore pop musicians' relationship to management on the music market of the 1960 s to 1990 os. In a third step, the theoretical positions and results concerning the past music market are contrasted with empirical findings 
on current self-management by musicians. These findings result from an interview study with independent musicians on digital distribution, self-management, and copyright, which I undertook from 2012 to 2014. Finally, I offer a synthesis of the lessons learned.

\section{THE ARTREPRENEUR AND SELF-MANAGEMENT}

The concept of the artrepreneur and the associated term musicpreneur dates from the period after the internet came into its own. Smudits coined the term in 2008 in reference to the digital music market. He used it to outline his idea of the musician's position on the music market of the future:

A realistic picture of music producers in future developments is as small business owners, as "artrepreneurs" with diverse skills, mainly technical, commercial and artistic, but also with activities oriented towards diverse professional fields, as composers of 'art music' as well as applied music, as sound designers, disc jockeys, producers etc. Nor is it unlikely that (unsaleable) artistically ambitious work will be consciously produced and regarded as a 'creative business card', in order to acquire commissions from the business world (and less and less from public authorities). (Smudits 263; translation mine)

A key point of this concept is that the musician appears as an entrepreneur who understands music itself as only one of many activities. Economic skills are demanded to an equal degree. Secondly, Smudits abandons the idea that musicians can earn money through music with artistic pretensions. He sees classical and pop musicians as being in the same position. The ideal of autonomous artistic production, which arrived in the field of popular music during the 1960s, appears to be on a general decline once again. According to Smudits, musicians in the future will earn their money primarily by providing services.

Engelmann et al. take up the concept of the artrepreneur and see classical musicians in particular as facing the task of acquiring skills in addition to their musical competence, especially those oriented to marketing their work. Maintaining networks will be the focus of the new type of artrepreneur's activities: "The new artrepreneur therefore is not only skilled as a musician but he/she will incorporate and learn various other skills to provide value for his/her network" (Engelmann et al. 40). The authors see the new networking possibilities, which they will need to master, as both an opportunity and a challenge for musicians. Paulus and Winter also view the strategic networking of musicians and music listeners as the central new activity of musicians as "media-artepreneurs" (37). 
Kubacki and Croft use the concept of the musicpreneur to characterize successful jazz musicians in a comparative case study set in Poland: The "Musicpreneur' perceived himself in opposition to struggling artists, a market player and identityengineer with absolute trust in the market structures, consciously using his artistic identity in managing his market identity" (815). They describe the musicpreneur as the confident manager of his own brand, who has internalized a self-image as an entrepreneur. The term emerged through the characterization of a single case in the context of a small-scale empirical study. Kubacki and Croft also describe two other cases: the "artistic integrity promoter," for whom artistic integrity is the most important issue internally and externally, preferring to leave management to professional partners (811), and the "nonconformist artist," who is very critical of the mechanisms of the music market, even if she is very successful within these structures. The nonconformist artist places emphasis on artistic and creative independence, accepting no contracts associated with extra-musical interests (e.g. corporate interests) and attempting to access alternative career paths (813). Finally, Kubacki and Croft summarize their findings with the suggestion that musicians assess their music-related skills more highly by comparison to their management activities.

In her book chapter, “The Artistic Entrepreneur," Jen Harvie draws attention to the normative quality associated with the concept of the artrepreneur in the context of the creative industries debate. "[C]urrent social, economic and political contexts," Harvie writes, "are radically reconfiguring what an artist is expected to be and, in so doing, putting the value of being an artist at serious ideological risk" (62). She explicates the ideological function of the concept of the artist as entrepreneur in current debates, which may also be termed hegemonic. This disposition restricts the substantive scope of artistic activity, as it is applied in a normative way. Artists who internalize the subjectivity of an entrepreneur can no longer work critically with respect to current capitalist developments. Despite her substantial criticism, Harvie does note that some abilities demanded from artists by the concept of the artistic entrepreneur were necessary or helpful in their past struggle for artistic and economic survival. Indeed, since the 18th century at the latest, musicians and other artists have found themselves in a specific field of tension: on the one hand, the artist was understood as a radically free, creative genius; on the other hand, artists needed to pursue their careers in a cultural field increasingly organized according to market forms and to relate to the mechanisms of this same field (cf. Harvie 64).

To sum up, we can see that the concept of the artrepreneur constructs an artistic personality which integrates artistic-creative and economic, marketingoriented competencies. Economic activities are upgraded in comparison to the classic, romantic ideal of the artist: they are no longer hidden or rejected, but are demanded as standard activities of equal value. If this is true, who has put such 
demands on the musicians? Furthermore, the work of Kubacki and Crofts indicates that at least some musicians embody an entrepreneurial self-understanding-but to what extent can this assertion be generalized? In preparation for answers, we look next at the role of musicians within the economy of the 1960 s to 1990 os music market, especially at the rise of the amateur musician.

\section{MUSICIANS AS CUSTOMERS}

During the 1960s, pop-music changed its character substantially. This change can only be touched on briefly here; it has been discussed in detail since the 1970s. ${ }^{5}$ From dance music with stereotypical lyrics, pop music turned in part into a tool of individualistic expression (mainly for young white men). The Beatles's album, Sgt. Peppers, is seen as an iconic record representing this turn. All over the Western world, young people adopted the new rock music as conveyed by the media, along with the associated images, attitudes, and value systems. Rock musicians became role models and a starting point for many listeners to make music themselves. The instruments and amplifier systems necessary for such practice were offered by a fast-growing industry.

Jim Marshall's company Marshall Amplifiers, based in London, found itself in the center of this development. In the late 196os, their new amplifier models became very popular among well-known rock musicians. Marshall handed the distribution over to the well-established British manufacturer and distributor Rose Morris, whose own factories worked 24 hours a day to meet the demand for electric guitars and drum sets. ${ }^{6}$ Sometime in late 1966, Rose Morris started an advertising campaign for Marshall amplifiers with the claim, "The sound of success - MARSHALL." It appears that this claim was used for several years. Advertisements from the Melody Maker in autumn 1967 show the claim together with drawings of famous musicians like Roy Orbison and Jimi Hendrix (see figure 1). In a 1974 interview with Jim Marshall, the claim was quoted to create the headline: "Pop went for the sound of success" (Maloof 88).

Campaigns such as this were not aimed at the established musicians of the time such as John Lennon, Pete Townshend, or Eric Burdon. They were aimed at all those who wanted to emulate them. The claim suggests that even if success itself proved elusive, at least the sound of pop-musical success could be attained by purchasing these amplifiers, which made their owners sound like successful musicians. The claim captures a central mechanism of rock music's active, local appropriation. The amateur rock musicians are addressed as a central target group for instrument manufacturers and service providers on the music market until 


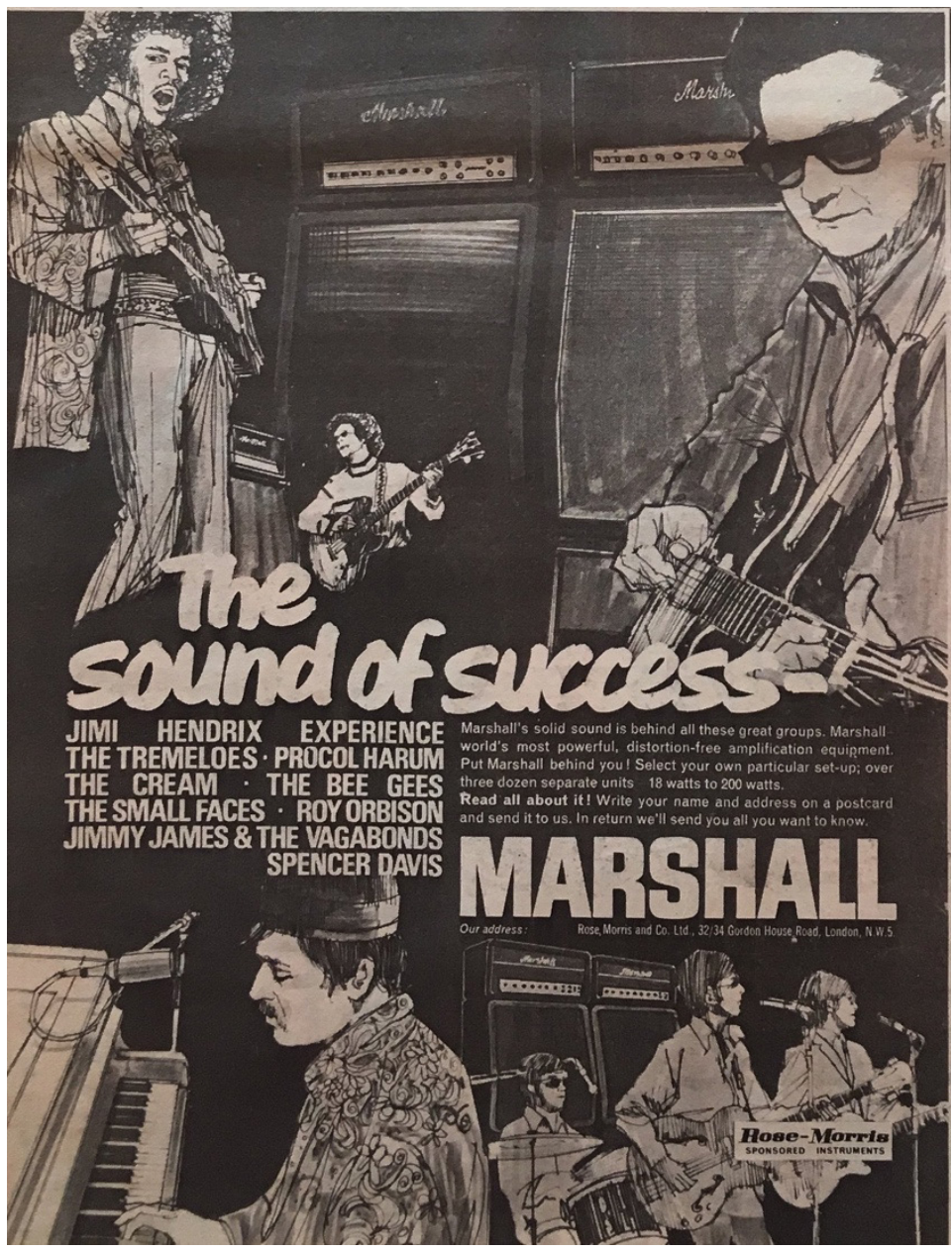

Figure 1: Marshall advertisement from Melody Maker magazine, 25 Nov. 1967

today: They buy instruments and rent rehearsal space, book recording studios and, in some cases, invest large sums of money earned elsewhere for their musical activities. The broad-scale production of popular music has been a field of amateur production at least since the late 1960s (Hemming; Robinson 149); in fact, only a small proportion of musicians are able to earn a living with self-created pop music.

\section{SELF-MANAGEMENT BEFORE THE INTERNET}

In regard to management, self-marketing for the amateur is always the starting point and it is unavoidable for most musicians: There is usually no one outside the group 
or solo musician who is willing to take on this time-consuming and unpaid task. The amateur musician is defined here, following Herzberg, as someone who spends a substantial portion of her time on music-related activities but who generates little or no income with this activity (35). The word "amateur" was also used by the musicians themselves at that time. An evaluation of contemporary studies shows that pop musicians in the 1970s to 1990 os used the chain of terms amateur, semi-professional, and professional to describe key categories when assessing their own activities and distinguishing themselves from other musicians. ${ }^{7}$ The semiprofessional generated some portion of his livelihood from his musical activities. The professional was the most highly regarded among musicians, because he or she could live from making music.

Both an economic understanding and a value system were linked to the chain of terms explained above. Success on the music market represented a central measurement factor in this value system; and among musicians, success was calculated by economic status. The musician's goal was a record contract, and selfmanagement was viewed as a necessary evil on route to it. The general idea was that self-management ends with the recording contract; then, at the latest, a manager or a record company will take over the corresponding tasks. This idea can be termed general because all those involved agreed with this assessment of the ideal career path: musicians, the music press, books of advice, and contemporary pop music researchers. An example is a practical 300-page guidebook for musicians that carries the subtitle "Tips for Musicians from the First Concert to the Record Contract" (Hentschel; translation mine). It aims at aspiring amateur musicians who wanted to prepare for entering the music market.

This preoccupation can also be found in the few studies concerning the working conditions of artists. In 1988, for example, Wills and Cooper published a study about stress among British pop musicians. Their work mentioned insecurity concerning career opportunities as a factor but discussed self-management only in the context of the problems in negotiations with big business partners; foremost record labels were elaborated. Stress over the acquisition of concerts, contracts, or selforganization in general was only mentioned as a side note (Wills and Cooper 110). Here too, "real" participation in the music market starts with deals that musicians are able to make with big companies. Simon Frith takes a similar perspective when he writes in his very influential book on the politics of rock music: "The show-biz recipe for rock success is 'sufficient talent, efficient management and an enterprising record company', and the central ingredient in this recipe is indeed the company: The company makes its equipment available to musicians to turn their music into saleable mass commodities" (109). This common notion contradicts musicians' everyday reality in unusual and revealing ways: Only few musicians succeed in obtaining a recording contract with a large or small record company, and only a 
small number of these in turn manage to earn substantial money from record sales and concert revenue. The vast majority of musicians generate little revenue with their pop-musical activities and only reach a limited audience: They are dependent on self-management all their lives (or throughout their participation in the field).

How can this contradiction be explained? A theoretical classification particularly helpful in this context can be found in Bourdieu's theory of social fields. According to Bourdieu, social space is divided into different areas, which he refers to as fields (Bourdieu, Die Regeln Der Kunst). Social struggles based on interests take place here according to established rules of the specific game that is being played in the field. Fields are limited by the respective rules' range of validity. Bourdieu called faith in the meaningfulness of each game the "illusio." As this illusio needs to be shared among all participants, they become accomplices (Bourdieu, Die feinen Unterschiede 389). Together, they replicate and stabilize the game by constantly acting out its rules and sharing the central beliefs of the field. Among other things, this illusio is conveyed via the possible rewards available; they motivate the participants to join in and stick to the rules of the game. From the outside it can be obvious that those rewards are illusions, but within the field their credibility is beyond doubt.

If the music market is understood as a (playing) field, from the 1960 s to the 1990s, the record deal appeared as a key reward and an important indicator for the defining value category in the field: the sweet sound of success. The record contract constituted a central anchorage point, a turning point in the game, the moment a musician "made it." The pursuit of a record deal made the game seem meaningful and worthwhile. On the one hand, it motivated many musicians and other persons to participate in the pop-cultural production. At the same time, the illusio ensured that the participants adhered to the rules that perpetuated the prevailing power structures for it is also a means by which the participants are deceived regarding the actual social power structures in their field, and thus their actual chances. The recording contract appeared essential for this mechanism in this particular historical constellation: It was the career goal of almost all participating musicians, but when seen from the outside, it becomes clear that it remained unattainable for most.

The illusio was opposed to a professional reality marked by invisibility and major hurdles. The music market can be described as a field dynamized by the logic of success. Success is an excluding criterion, and thus the power structures in the music market consist of networks of exclusion. The terms "gatekeeper" or "intermediary," often used in analyses of the workings of the music market, describe persons in key functions with switching power over this exclusion: journalists, club owners, promoters, $\mathrm{A}+\mathrm{R}$ managers at record labels, radio DJs, and so forth. 
Musicians must get these intermediaries to cooperate with their own career goals, in order to have any chance at climbing the decisive ladder to success (cf. Scott 239).

In 1988, Tony Kirschner identified four levels in his model of pop-music success, constituted across several dimensions. One central criterion was geographical dissemination, and Kirschner divided this dissemination into four levels: local, regional, national, and international (251). Each of these levels is difficult to surmount. It is not even easy to get from the local to the regional level. Musicians can make a name for themselves locally, starting out from circles of friends and acquaintances, and the local press typically reserves a place for local culture. Fifty miles further away, things already look different, because organizers are averse to booking musicians who are unknown in a place. The local press has no need to support musicians from the neighboring town. Fame outside the local context is only really generated through media presence, through sound recordings, reports in the press, and others. To achieve a nationwide media presence through selfmanagement without obtaining the support of a record label is very difficult. It takes much industry knowledge, time, and money-more than what amateurs usually have at their disposal. Because of this, the musicians of one town remain invisible to audiences in other towns. Primarily, it is those actors who have reached the level of national or international distribution who are visible in the media. This is true not only of mainstream artists, but also of musicians in the subcultures. In the 1970 s and 1980 os alternative music cultures like Punk and New Wave, analogue market structures emerged with identical logics of distribution and success.

\section{INTERNET: SWITCHING ON THE SPOTLIGHT}

The establishment of the internet brought a fundamental change to this game: It radically reduced the costs that were necessary to generate supra-regional, or even global, media availability. The result was that the incredible amount of amateur music in the world suddenly became widely visible. In addition, since the late 1980 os, there were ever-declining costs of media production as a result of the digital mediamorphosis: More and more music products were realized by amateurs in home studios (Poschardt 373) and made digitally available. This interaction had profound effects on the music market. New offers and services emerged for musicians, contact with fans and other musicians was reorganized, and new social spaces emerged on internet platforms where appropriate forms of behavior and marketing strategies could be tested. Furthermore, diverse new forms of creative expression like remixes, mash-ups, and musical memes emerged and were disseminated online. 
In research on digitization, a large number of theoretical models evolved, which explored the opportunities for stakeholders as a consequence of these processesand a certain euphoria resonated in many of these models. Terms that diagnosed the deconstruction of old barriers to access and suggested new power relations were often used. Here, briefly, are some prominent examples: democratization (Hippel; Sperlich), culture of sharing (Aigrain), remix culture (Lessig, Remix), pro-am revolution (Leadbeater and Miller), prosumer cultures (Abresch; Bruns), long tail (Anderson), and the wealth of networks (Benkler). Many authors examined the new (or now visible) creative protagonists, and in most cases, musicians were considered as a subset of users and only rarely subject to explicit examination.

If this new attention to participation processes is applied as a research perspective to the period before the internet, as in the present article, it becomes clear through retrospective consideration that the share of amateur production on the music market before the internet has been underestimated in research on the music industry to date. ${ }^{8}$ The transmitter/receiver model originating from communication theory (Shannon and Weaver) and its counterpart of producer/ consumer in economic theory can only incompletely describe the dynamics in media markets of cultural production. With the internet, a structure evolved that not only made such activities visible but also rewarded them, reinforcing the new structure in turn.

Internet platforms became the new key actors in the management of this visibility and the modeling of corresponding dynamics. MySpace was the first major example as a playground for musicians; today YouTube is the leader, but many other, specialized platforms exist. Some platforms help with the sale of music or with the coordination of self-management or social media activities. Much has been written about the opportunities for activity on such platforms. ${ }^{9}$ However, researchers have seldom addressed the key importance for all these providers: that as many people as possible participate in this game. How do the platforms invite musicians to join in? Soundcloud, a platform where musicians can offer their music free of charge for others to listen to and comment on, presents itself as a central tool for aspiring musicians. The platform promises more reach and knowledge about the musicians' fanbase: "SoundCloud gives you the tools to level up your career."10 In the 2016 version of the promotional page, the platform emphasized the importance of regular engagement with the platform in order to achieve this goal: "Share your tracks [...] Grow your audience. [...] The more active you are in the community, the more you'll grow your fanbase." ${ }^{11}$ Today they focus the two main features of the platform in one claim: "Connect with fans and see who's listening."

The platform Bandcamp has a different, more traditional distribution orientation. Musicians upload albums and set a price for them; fans can buy records and follow 
musicians. Interaction is not such a big factor here; instead Bandcamp focuses on possible monetization. In an ironic tone typical of the platform's self-presentation, Bandcamp even prophecies that it will rain money: "Why, dear musician friend, are you not yet yourself twirling with arms spread beneath this gentle shower of silver and gold? Read on and be further convinced, or simply - sign up now!"12 Despite the self-irony, the central advertising message remains: Bandcamp will help musicians to generate income. Overall, however, the offers mentioned (like many others as well) do not constitute active assistance in any form, but merely an automated service. The account holders themselves have to add their music and advertise (elsewhere), so that people are encouraged to comment on the music or download it. ${ }^{13}$

Gumroad.com is a sales platform for independent authors and other creatives, similar to Bandcamp. There, for \$5, David Andrew Wiebe provides the advice manual "What it means to be a musicpreneur" and advertises it as follows: "by and large, music entrepreneurship is unexplored territory.... It denotes a fundamental shift in one's approach to building a music career. It's a new paradigm. [...] Ultimately, it's about living a more fulfilling, more purposeful life."14 Wiebe, together with many other entrepreneurs and platforms, ${ }^{15}$ is one of the service providers offering musicians help with the selection and application of online marketing opportunities. The advertising messages analyzed here show that all these providers proclaim a positive attitude towards self-management. They promise growing chances of success when musicians participate on platforms or use digital services like those mentioned above.

Alongside the transformation of musicians' entrepreneurship, political stakeholders were constructing a new branch of the cultural and creative industries as a project representing a growth-driver for the world economy. ${ }^{16}$ The success likewise depended on having many participants. One official report noted quite fittingly that these industries are very fragmented in structure and contains many self-employed and micro entrepreneurs (cf. Söndermann 8). Because the creative industries are a concept that renders cultural activities under an economical paradigm, participants' activities need to be explicated under the primacy of economic thinking. Upon closer inspection, it becomes clear that many of these small players make very little money so the concept of value is being expanded. It is still business, but it is no longer about simple productivity measurable in monetary terms. Rather, growing attention is paid to the social and cultural levels of added value. ${ }^{17}$ The potential to earn money by using self-produced and distributed music is only one possible gain in the calculation of the new multi-dimensional creation of value in networks (Bürkner and Lange; Hutter; Reinke)-developing a reputation and the awareness of mutual obligations in social networks appear equally important (Scott). This, too, is an effect of the amateurs' visibility being 
conceptualized within the frameworks of new theories of cultural economy. Today, self-management appears as a legitimate tool to build up cultural, social, and economic capital.

We have identified internet platforms and cultural industry promoters as influential parties that emphasize entrepreneurial subjectivities among creators. To sum it up, the artrepreneur evolves as a new concept for artists' subjectivation out of the undeniable fascination emanating from the dynamics of digital cultural production, which are reflected not only in influential theoretical models, but also in marketing interests and ideological concepts. The basis of this development is the new visibility and importance of the amateurs as content generators. These findings are in keeping with key contemporary demands for subjectivation. Reckwitz coined the term "creativity dispositive" (15) to describe the social knowledge structure in which the individual's most valuable cultural and economic contributions lie in constantly generating the new as an expression of his or her individuality. There is also a link to the notion of individual lifestyles as economic enterprises, as described by Bröckling in his analysis of the entrepreneurial self (283). The concept of the artrepreneur is compatible with the agenda of the cultural and creative industries, where terms are being sought that suggest competence to act in an economic fashion for minor and even the smallest protagonists, scarcely noticed until recently.

We have found some evidence for Harvie's claim that the new subjectivity of the artrepreneur is brought into the field via a realignment of promised incentives (cf. Harvie 62). Some musicians and other creative workers have been taking a public stand against the normative requirements associated with the concept of the artrepreneur, and they often reflect on this in a critical way. As a keynote speaker at the AmericanaFest 2016 in Nashville, T Bone Burnett said:

We live in a time in which artists are being stampeded from one bad deal to another worse deal. No one asks the artists. We are told to get good at marketing. I have to sayand I think I probably speak for every musician here-that I didn't start playing music because I sought, or thought it would lead to, a career in marketing. ${ }^{18}$

Burnett explained that he perceives conceptions of the musician as a creative entrepreneur as a program imposed from the outside, which he does not wish to follow. Another example of perceived outside pressure is the 10-point plan developed by the Coalition of the Independent Scene (Koalition der freien Szene) in Berlin. There, we read, "Creative industries, the promotion of tourism, educational and social measures are not the tasks of art and should not be financed from the budget for culture." ${ }^{19}$ The artists organized in this context have kept their distance from the concept of the creative economy and thus maintain, on a fundamental 
level, that they do not see themselves as entrepreneurs within the framework of the concept.

In the present music market, as has been shown, there is a spectrum of parties with an interest in the participation of as many musicians as possible who are interested in pursuing musical careers. Such parties use the subjectivation mode encapsuled in the concept of the artrepreneur to motivate field participation and consequently the expenditure of time and money in the game. Is a new vision forming here as part of a new illusio, an illusio that claims self-management as the new central strategy? To function as an illusio, this concept must be shared by all participants in the game. We have seen that at least some musicians resist it. Therefore, it is necessary to investigate the self-concept adopted by those now offering their music on this new market more closely. What artistic and marketing strategies do they pursue, and how do they balance music-related and management activities?

\section{DIGITAL SELF-MANAGEMENT}

In order to gain insights into this issue, I reexamined interviews originally conducted for a study on digital distribution, self-management, and copyright use by self-employed musicians (Schwetter). For this study, I interviewed 15 musicians from Germany and the USA who organize their own management at various stages in their careers. In addition, five interviews with musician's business partners were conducted, and three group discussions with amateur musicians from a study dating from the early 1980 os were re-evaluated. Due to the fact that only few studies have been undertaken in this area, a grounded theory approach was chosen to create an exploratory research design. The interpretation aimed to identify central themes and strategies concerning self-management. Some of the interviewed musicians do self-management today after having had typical careers in the music industry; now they are convinced self-marketers. Others have always practiced selfmarketing. The following summarizes some findings of these surveys in relation to self-management and the associated professional self-image.

The interviews from the 1980 os approve the argument that was developed above in section four. Self-management was considered unavoidable, aimed primarily at acquiring a record contract. For today's musicians this is different: the selfmanagement of a musical career is understood as a strategy that can be pursued perfectly legitimately, even in the established career stage. 
I feel like I have been self-managed and all the big tours and all the big opportunities that I have gotten have been through my own contacts. I really think especially in today's market an artist has to do this, you know. There's just not that much money on the table, you sure as hell can't afford to give away fifteen or twenty percent. It's a big chunk. (Song2, paragraph 51$)^{20}$

The reason that I wanted to do this myself is so that I could be my own boss and make my own decisions. (Song4, paragraph 300)

For some musicians, self-management is the strategy of choice, connected with a feeling of empowerment, while others take a more pragmatic approach. On a music market where revenue streams are becoming smaller and resources more rare, musicians try to eliminate the need for intermediaries and partners who will claim shares of their revenue. These include in particular classic partners like record labels, music publishers, or booking agencies.

I'm my own manager, I'm my own booking agent. You know, I spend a lot of time writing e-mails. So, I mean I could almost say [laughs] I'm an e-mail-writer rather than a musician. (Song5, paragraph 22)

On the other hand, self-management is a double-edged sword with no alternative for many musicians, since they cannot pay anyone to assume substantial tasks. The management and marketing measures take up large parts of their time budget, leading to conflicts with their musical and creative activities. This conflict was an important issue in all interviews. The creative work is regularly pushed into the background.

I have friends, they are so sovereign with telling all the people, they are the hottest acts around, and the people believe it! (laughs) [...] But of course that's part of the business, that's clear. It's very hard to sell yourself. That's just something I've never been good at. (Rap1, paragraph 203; translation mine)

Managing time budgets is not the only issue. For some musicians, self-promotion feels easy; for others, it is quite difficult on an emotional and psychological level. This is true even for those who generally embrace self-management as a means of liberation from corporate influence (like Rap1). It might be that a certain type of personality suits the needs of self-management better than others.

In sum, all the musicians interviewed would like relief and support in management. Given sufficient revenue, they prefer to employ assistants, managers, etc. Some musicians become heads of their own companies in this way. Others join together and set up shared infrastructures. Both strategies, by the way, are 
not new; they were also evident in the time before the internet. ${ }^{21}$ As in that period, the musicians interviewed see their creative work as the more valuable activity and their core competence, no matter where they are in their career and in what genre. ${ }^{22}$ Overall, therefore, today self-management is located in a paradoxical field of conflict between necessity, empowerment, and excessive demands.

By comparison to definitions from the pre-Internet era, the professional image of the musician in pop culture has remained unchanged for the interview partners. The most important criterion for the occupational status of musician is whether one earns a livelihood or not with one's own artistically and independently produced music. These results do not confirm a shift in self-image away from monetaryeconomic ideas to concepts of a reputation. Professional definitions from creative industry research such as the creative entrepreneur or artrepreneur have only partly found their way into musician's self-descriptions. While self-management is legitimate, people who describe themselves as musicians but fund their musical activities from other work are regarded with skepticism by their musician colleagues.

This professional self-image contrasts immensely with the musician's actual chances of success, just as it did from the 1960s to 1990s. A majority of the interviewed experts and musicians considers it highly unlikely that an independent musician will be able to earn his own livelihood in Germany today. Some participants consider it out of the question to generate a lasting income, that is, to develop a career perspective that could ensure one's existence over time and support a family. For musicians in the early and mid-stages of their careers in Germany, the financial situation has not deteriorated because of digital distribution opportunities and the associated radical changes in the music market-it was already very problematic in the past. ${ }^{23}$ In the established career stage, the situation for musicians is more difficult today because the market is smaller overall. Here, self-management may prove an advantage.

As already stated above, the digital mediamorphosis has given independent musicians access to professional production conditions and to multiple distribution channels, but with respect to marketing as a central means to make music known, something similar can be observed only to a very minor degree. Although a lot of new platforms and possibilities for interaction have arisen for self-promotion, these new channels have not overridden the hierarchies of the old music market. Based on their own experiences with social media campaigns, most of the musicians interviewed conclude that audience-based marketing cannot replace the old structures, but only complement them. Promotion as a pivotal point in getting music known requires the expenditure of time and money. The advantages of the music industry are good contacts with other intermediaries, experience in campaign planning, and capital to finance them. Today, marketing is being largely 
outsourced by the major record labels to independent agencies, which can also be booked by independent musicians, but they have to be able to pay for such work. Access to press, radio and other intermediaries is only available to those who can harness the necessary capital.

\section{DISCUSSION AND CONCLUSION}

The developments triggered by the digitalization and current restructuring of the economy brought fresh awareness concerning the processes and activities of self-marketing, which have been important for musicians for a long time, but were masked by the illusio of the 1960 s to 1990 os music market. Belief in the recording contract as a central component of the illusio of the field made people forget the everyday reality of self-management at that time.

The internet has made the amateur production of popular music widely visible, and the music market has changed dramatically. But the old market structures have not disappeared. In addition to the old intermediaries, new ones have emerged-first and foremost Internet platforms - that offer forms of participation or help with self-marketing and woo amateurs as their customers. New dynamics are emerging due to more easily facilitated participation in music distribution processes. The request to join in, which musicians and internet users in general encounter in various forms today, should be understood as the central message. It is possible that today young people and aspiring musicians participate in these processes more than ever. At least as content-providers, they are becoming an integral part of media markets.

The old media companies are far from being obsolete. They still have a big influence in the marketing and promotion of music, and they adapt their strategies to the new developments mentioned above. For example, they co-own multi-channel networks (MCNs) for user content on YouTube. Such MCNs help YouTube users to maximize their reach: They organize cross-promotion and product placements and in return demand a share of the revenue (Grünewald). The MCNs stay in the background and for the average YouTube user they remain invisible. The content appears to be created independently. Thus, the idea of becoming a YouTube star yourself by just adding content to the platform remains promising.

Additionally, it should be mentioned that the old market structures did not disappear. Records are still being produced and marketed with the help of intermediaries like major record labels, radio stations, and others. The record labels react to the changing market and shifting income possibilities through offering 
artists so called "36o-degree deals," demanding shares from all revenue streams of the artists (Anderson) while expecting them to publicly pursue self-promotion and engage with their fans (e.g. on social media sites).

Self-publishing and self-management with the aid of digital communication and music distribution tools have become a new leitbild. This leitbild is becoming part of a new illusio as a fresh, shared belief in the meaning of the game. The changes brought by the digital mediamorphosis rendered the illusio of the record contract useless. Most musicians still value their creative work more highly than their management skills and aim towards the career goal of living from their creative work. In this respect, they do not incorporate an "artrepreneurial" subjectivity. But while the self-image and the career goals of musicians remain nearly unchanged, the shared belief on how to reach these goals has changed dramatically. Selfmanagement appears as a new, central career strategy that promises success while the chances are as few as ever. Whereas with the illusio of the record contract the importance of self-management was blurred from the 1960s to 1990s, today it is the other way around: The importance of the intermediaries is blurred by focusing on self-promotion. Due to the fact that the belief in self-promotion and management encourages participation in the game of the music market while hiding the underlying power structures of (old and new) intermediaries, it can well be said that the concept of the artrepreneur is part of a new illusio in the music market. But whatever way the rewards and promises of the music market turn; today, as in the days before the internet, self-management remains an activity with no alternative for most musicians.

In future studies it might be interesting to look at musicians stepping out of musical activities and how such exits may be an advancement in careers. Many musicians earn money with music-related jobs in the music market, and most experts in the music market that I interviewed were active as musicians some time during their earlier career. Activity as a musician may function as a door-opener to other job opportunities and activities that offer greater economic potential than making music. It would thus be instructive to explore such biographical turning points empirically throughout the history of the music market. Maybe we find that stepping out of the musical career may not necessarily be a failure. Instead popmusical activity might also function as a qualification and stirrup for careers in other jobs in the music market. 


\section{Notes}

1. On this, confer, for example, Grassmuck; Lessig "Free Culture"; Schimana; and Tschmuck. The literature cited in this paper is written either in English or German.

2. To avoid any impression of gender bias in the group of people addressed as musicians, masculine and feminine forms will be used at random.

3. Two examples from European cultural history may be highlighted in this context: Nineteenth century virtuosi were usually their own concert organizers. We know that Nicolo Paganini, the so-called devil's violinist, insisted on always sitting at the box office himself and handling the evening's takings (Kuhnke et al. 38). Johann Wolfgang von Goethe also self-published his first work, "Götz von Berlichingen," at his own cost (Borchmeyer 35).

4. The term "field" is used here following Pierre Bourdieu's understanding. See part 4 of this article.

5. See, for instance, Frith 73.

6. See the official company history in "Rose Morris Always with Pleasure 1920 to 1970, Part 1." Rose Morris, https://rosemorris.com/pages/rose-morris-alwayswith-pleasure-1920-to-1970-part-1, accessed 8 May 2018.

7. Cf. Aschenbach 125; Hemming 9; Pellmann and Wilczek 270.

8. Some notable exceptions must be noticed here: Hemmings study on semiprofessional musicians in Germany and Robinson et al. international study on musicians in peripheries.

9. As examples, see Yew as well as van Dijck.

10. Soundcloud, https://soundcloud.com/upload, accessed 15 May 2018.

11. Soundcloud, https://on.soundcloud.com, accessed 23 Sept. 2016.

12. Bandcamp, https://bandcamp.com/artists, accessed 15 May 2018

13. Cf. Herzberg for a more detailed presentation of the commercial utilization of participant activities on internet platforms.

14. David Andrew Weibe, "What It Means to Be a Musicpreneur." Gumroad, https:// gumroad.com/1/yjPkG\#, accessed 26 Sept. 2016.

15. On this, confer, for example, Baker and Kachelrieß.

16. As a prominent example see the Creative Industries Mapping Document by the Department for Culture, Media \& Sport, City of London.

17. It is revealing to look at the definitions of market participants as they are constructed in empirical studies to define the respective data sample. For example, for an "economic study of professional artists in Australia," Throsby and Zednik define the professional artist as someone who seriously strives to be an artist and delivers high quality output, "even if creative work is not the main source of income" (16). In the 1990s, this criterion was part of definitions of the amateur (Kirschner) or the semi-professional (Hemming). To use this aim to define the professional artist in an economic study shows a shift in academic thinking when aiming to define the scope of the creative industries. 
18. T Bone Burnett, Keynote AmericanaFest 2016, Nashville, 20.09.2016. Quoted from http://nodepression.com/article/music-confounds-machines, retrieved 23.09.2016

19. http://www.berlinvisit.org/10-punkte-2016/, accessed 10 Dec. 2016 and translated by the author.

20. For the study a matrix was created to include musicians from all major popular music cultures. Instead of using popular music styles (like rock, pop, heavy metal, techno) to distinguish musicians, three analytical categories were developed under which the styles can be subsumed: Song culture, rap culture, track culture. The interviewees' aliases were created using those categories and consecutive numbers.

21. As prominent German examples, one might point to Ton Steine Scherben and Einstürzende Neubauten. In 1976, the rock band Ton Steine Scherben founded the music publisher April together with three other bands (Biegert); in 1982, it participated in the foundation of the distributor EfA (Energie für Alle). Einstürzende Neubauten founded the music publisher Freibank in 1984. Today it is one of the biggest independent music publishers in Germany, providing services for many successful musicians.

22. This corresponds with Kubacki and Croft's findings.

23. Apart from one-off revenue from live performances, there was barely any earning potential. Although there were well-functioning independent structures in the German music market for periods in the 1980 os and 1990s, most of the musicians who used them could achieve only a little revenue in this way. 


\section{Works Cited}

Abresch, Sebastian. Prosumenten-Kulturen. Universität Siegen, 2009.

Aigrain, Philippe. Sharing: Culture and the Economy in the Internet Age. Edited by Suzanne Aigrain, Amsterdam UP, 2012.

Anderson, Chris. The Long Tail: How Endless Choice Is Creating Unlimited Demand. Random House, 2007.

Anderson, Tim J. Popular Music in a Digital Music Economy: Problems and Practices for an Emerging Service Industry. Hoboken, 2013.

Aschenbach, Matthias. "Professionelle Rockmusiker zwischen Musikalität und Geschäft." Begabung und Kreativität in der Populären Musik, edited by Günter Kleinen, Lit Verlag, 2003, pp. 125-52.

Baker, Bob. Guerilla Music Marketing Online: 129 Free and Low-Cost Strategies to Promote and Sell Your Music on the Internet. Spotlight Publications, 2011.

Bandcamp. 2007, https://bandcamp.com/artists, accessed 15 May 2018

Benkler, Yochai. The Wealth of Networks: How Social Production Transforms Markets and Freedom. Yale UP, 2006.

Biegert, Claus. "Die Alternative: Platten selber machen und Vertreiben." Rock Session 1, Magazin der populären Musik, edited by Jörg Gülden and Klaus Humann, Rowohlt, 1977, pp. 121-127.

Borchmeyer, Dieter. Goethe. DuMont Literatur und Kunst, 2005.

Bourdieu, Pierre. Die feinen Unterschiede: Kritik der gesellschaftlichen Urteilskraft. Translated by Bernd Schwibs and Achim Russer, Suhrkamp, 1987.

--. Die Regeln der Kunst: Genese und Struktur des literarischen Feldes. Translated by Bernd Schwibs and Achim Russer, 1st ed., Suhrkamp, 2001.

--. Sozialer Raum und "Klassen": Leçon Sur La Leçon; 2 Vorlesungen. 1st ed., Suhrkamp, 1985.

Bröckling, Ulrich. Das Unternehmerische Selbst. Soziologie einer Subjektivierungsform. 1. Aufl., Orig.-Ausg., Suhrkamp, 2007.

Bruns, Axel. Blogs, Wikipedia, Second Life, and Beyond: From Production to Produsage. Lang, 2008.

Bürkner, Hans-Joachim, and Bastian Lange. "Wertschöpfung in der Szenewirtschaft - Elektronische Clubmusikproduktion in Deutschland." Berlin Mitte Institut, 24 Aug. 2014, http://www.berlin-mitte-institut.de/ wertschoepfung-szenewirtschaft-elektronische-clubmusikproduktion-deutschland/.

DCMS. Creative Industries Mapping Documents 2001 - Foreword. Department for Culture, Media \& Sport, 2001, https://www.gov.uk/government/uploads/system/uploads/ attachment_data/file/183544/2001part1-foreword2001.pdf.

Dijck, José van. The Culture of Connectivity: A Critical History of Social Media. Oxford UP, 2013. 
Engelmann, Maike, Lorenz Grünewald and Julia Heinrich. "The New Artrepreneur - How Artists Can Thrive on a Networked Music Business." International Journal of Music Business Research, vol. 2, no. 1, 2012, pp. 31-45.

Frith, Simon. Sound Effects: Youth, Leisure, and the Politics of Rock. Constable, 1983. Grassmuck, Volker. "Re-mi-x-erogra-philist-er-kenntnisse. Zu Kunst und Recht der Re-Kreativität." Geistiges Wissen und Originalität. Zur Politik des Wissens und Kulturproduktion, edited by Odin Kroeger, Günther Friesinger, Paul Lohberger and Eberhard Ortland. Turia + Kant, 2011, pp. 199-214.

Grünewald, Lorenz. "Die Produktivität von YouTubes Musikkultur. Skizze Einer Theorie von Werte-Schöpfung mit digitalen Netzwerkmedien." Produktivität von Musikkulturen, edited by Holger Schwetter, Hendrik Neubauer and Dennis Mathei. Springer VS, 2018, pp. 75-98.

Harvie, Jen. "The 'Artrepreneur': Artists and Entrepreneurialism." Fair Play - Art, Performance and Neoliberalism, Palgrave Macmillan, 2013, pp. 62-107.

Hegner, Victoria. "Seduced by the Field: Methodological Transgressions in Ethnography." Forum Qualitative Sozialforschung / Forum: Qualitative Social Research, vol. 14, no. 3, Art. 19, 2013.

Hemming, Jan. Begabung und Selbstkonzept. Lit, 2002.

Hentschel, Christian. Der Musiker-Guide: Tips für Musiker vom ersten Konzert bis zum Plattenvertrag. Schwarzkopf und Schwarzkopf, 1999.

Herzberg, Martin. Musik und Aufmerksamkeit im Internet: Musiker im Wettstreit um Publikum bei YouTube, Facebook \& Co. Tectum, 2012.

Hippel, Eric von. Democratizing Innovation. MIT Press, 2005.

Huber, Michael. "Digitale Musikproduktion und die Krise der Musikindustrie." Musikrezeption, Musikdistribution und Musikproduktion: Der Wandel des Wertschöpfungsnetzwerks in der Musikwirtschaft, edited by Gerhard Gensch et al., Deutscher Universitäts-Verlag, 2008.

Hutter, Michael. Neue Medienökonomik. Fink, 2006. HS Bibliothek.

Kachelrieß, Jörn. Selbstvermarktung für Musiker: Erfolgreich ohne Plattenvertrag. Strategien für Bandkonzeption, Onlinepräsentation, Eigenvertrieb und GuerillaMarketing. PPV-Medien, 2008.

Kirschner, Tony. "Studying Rock. Towards a Materialist Ethnography." Mapping the Beat: Popular Music and Contemporary Theory, edited by Thomas Swiss, Malden, 1998, pp. 247-268.

Koalition der freien Szene, Das 10 Punkte Programm 2016, Berlin 2016, http://www. koalition-der-freien-szene-berlin.de/10-punkte-2016/. Accessed 1o Dec. 2016.

Kubacki, Krzysztof, and Robin Croft. "Markets, Music and All That Jazz." European Journal of Marketing, edited by Roger Bennett, vol. 45, no. 5, 2011, pp. 805-21.

Kuhnke, Klaus, Manfred Miller and Peter Schulze. Geschichte der Pop-Musik. Eres Edition, Archiv für Populäre Musik, 1976.

Leadbeater, Charles, and Paul Miller. The Pro-Am Revolution: How Enthusiasts Are Changing Our Economy and Society. Demos, 2004.

Lessig, Lawrence. Free Culture: The Nature and Future of Creativity. Penguin, 2005. 
-. Remix: Making Art and Commerce Thrive in the Hybrid Economy. Bloomsbury, 2008.

Maloof, Rich. Jim Marshall, the Father of Loud: The Story of the Man behind the World's Most Famous Guitar Amplifiers. Backbeat Books, 2004.

O'Dair, Marcus. The Networked Record Industry: How Blockchain Technology Could Transform the Consumption and Monetisation of Recorded Music. Middlesex University, 2016.

Paulus, Aljoscha, and Carsten Winter. "Musiker als Media-Artepreneure? Digitale Netzwerkmedien als Produktionsmittel und neue Wertschöpfungsprozesse." Gravitationsfeld Pop: Was kann Pop? Was Will Popkulturwirtschaft? Konstellationen in Berlin und Anderswo, transcript, 2014, pp. 133-42.

Pellmann, Dirk, and Andreas Wilczek. Popularmusiker in der Provinz. Eine empirische Untersuchung über Osnabrücker Musikschaffende im Zeitraum der frühen 196oer bis späten 199oer Jahre. Universität Osnabrück, 1999.

Poschardt, Ulf. DJ-Culture. Diskjockeys und Popkultur. Rowohlt, 2001.

Reckwitz, Andreas. Die Erfindung der Kreativität: Zum Prozess gesellschaftlicher Ästhetisierung. Suhrkamp, 2012.

Reinke, Daniel. Neue Wertschöpfungsmöglichkeiten der Musikindustrie. Innovative Businessmodelle in Theorie und Praxis. Nomos, 2009.

Robinson, Deanna Campbell, Elisabeth B. Buck and Marlene Cuthbert. Music at the Margins: Popular Music and Cultural Diversity. Sage, 1991.

"Rose Morris Always with Pleasure 1920 to 1970, Part 1." Rose Morris, https://rosemorris. com/pages/rose-morris-always-with-pleasure-1920-to-1970-part-1. Accessed 8 May 2018.

Schimana, Markus. Das Urheberrecht - von Buchdruck bis Filesharing: Alte und neue Diskussionen im Zusammenhang mit dem Urheberschutz. Tectum-Verl., 2009.

Schwetter, Holger. Teilen - Und Dann? Kostenlose Musikdistribution, Selbstmanagement und Urheberrecht. Kassel UP, 2015.

Scott, Michael. "Cultural Entrepreneurs, Cultural Entrepreneurship: Music Producers Mobilising and Converting Bourdieu's Alternative Capitals." Poetics, vol. 40, no. 3, 2012, pp. $237-55$.

Shannon, Claude Elwood, and Warren Weaver. The Mathematical Theory of Communication. U of Illinois P, 1949.

Smudits, Alfred. Mediamorphosen des Kulturschaffens: Kunst und Kommunikationstechnologien im Wandel. Braumüller, 2002.

-.. "Soziologie der Musikproduktion." Musikrezeption, Musikdistribution und Musikproduktion. Der Wandel des Wertschöpfungsnetzwerks in der Musikwirtschaft, edited by Gerhard Gensch, Eva Maria Stöckler and Peter Tschmuck. Gabler, 2008, pp. 241-65.

Soundcloud. 2008, https://soundcloud.com. Accessed 15 May 2018.

Söndermann, Michael. Forschungsbericht Nr. 589: Monitoring zu ausgewählten wirtschaftlichen Eckdaten der Kultur- und Kreativwirtschaft 2009. Kurzfassung. Bundesministerium für Wirtschaft und Technologie (BMWi), 2010. 
Sperlich, Regina. Popularmusik in der digitalen Mediamorphose: Wandel des Musikschaffens von Rock- und Elektronischer Musik in Österreich. Edited by Alfred Smudits, 1. Aufl., Deutscher Universitäts-Verlag, 2007.

Throsby, Charles D., and Anita Zednik. Do You Really Expect to Get Paid? An Economic Study of Professional Artists in Australia. Australia Council for the Arts, 2010.

Tschmuck, Peter. "Vom Tonträger zur Musikdienstleistung: Der Paradigmenwechsel in der Musikindustrie." Musikrezeption, Musikdistribution und Musikproduktion: Der Wandel des Wertschöpfungsnetzwerks in der Musikwirtschaft, edited by Gerhard Gensch et al., Deutscher Universitäts-Verlag, 2008, pp. 141-62.

Weibe, David Andrew. "What It Means to Be a Musicpreneur." Gumroad, https:/gumroad. com/l/yjPkG\#. Accessed 26 Sept. 2016.

Wills, Geoff, and Cary Lynn Cooper. Pressure Sensitive: Popular Musicians under Stress. Sage, 1988.

Yew, Jude. CcMixter: A Study of Motivations and Emergent Creative Practices that Results from Open Sharing and Remixing. Free Culture Research Workshop, Harvard Law School, Boston 2009. 